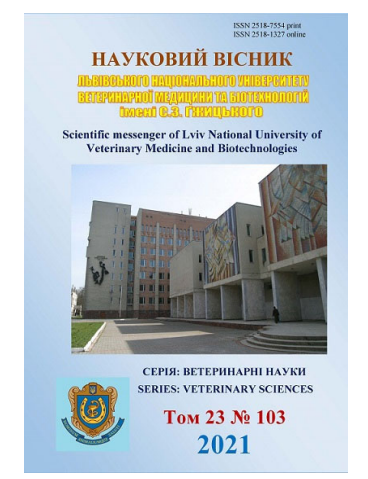

\author{
Науковий вісник Дьвівського національного університету \\ ветеринарної медицини та біотехнодогій імені С.3. Гжицького. \\ Серія: Ветеринарні науки \\ Scientific Messenger of Lviv National University \\ of Veterinary Medicine and Biotechnologies. \\ Series: Veterinary sciences
}

UDC 591.4:591.441

\title{
Morphology of the chicken sleep and its changes during vaccination
}

\author{
S. V. Guralska, T. S. Budnik \\ Polissya National University, Zhytomyr, Ukraine
}

Article info

Received 14.06.2021

Received in revised form 19.07.2021

Accepted 20.07.2021

Polissia National University, Stary Boulevard, 7, Zhytomyr, 10008, Ukraine.

Tel.: +38-067-410-91-56 $+38-068-411-47-65$ E-mail: tatjanabudnik@ukr.net svitlana.huralska@polissiauniver. edu.ua
Guralska, S. V., \& Budnik, T. S. (2021). Morphology of the chicken sleep and its changes during vaccination. Scientific Messenger of Lviv National University of Veterinary Medicine and Biotechnologies. Series: Veterinary sciences, 23(103), 3-9. doi: 10.32718/nvlvet10301

A significant number of scientific work has been dedicated to the study of immunogenesis processes in birds vaccinated to infectious diseases. In most contingency, research is aimed at assessing postvaccination immunity, as well as establishing structural changes in the immune system. But, exactly morphological studies that can provide an objective account of the immune effectiveness of the vaccine and assess the state of the body's immune system. However, today, morphological control of the immune status of chickens in the post-vaccination period has not been multitudinous used in practical poultry farming. Creating new vaccine prevention schemes, experts do not take into account the changes that manifested during this period. The purpose of the article - Is to systematize and describe the main results of research on the morphology of the spleen of chickens during vaccination. It should be noted that infectious diseases of birds, occupied a special place are: infectious bursal disease, infectious bronchitis, Newcastle disease, infectious laryngotracheitis, etc. Now, these diseases are registered in almost all countries of the world and bring significant economic losses to poultry farms. The main morphological changes in the spleen of chickens during vaccination include hyperplastic processes (lymphocyte proliferation and enlargement of macrophages), the appearance of blast cells, the development of plasma cell reactions. Morphofunctional changes in the spleen of chickens during vaccination are reflected in a significant amount of literature, but changes in the body that occur with multiplex vaccinations during complex vaccination schemes are not enough covered. This review article put a short description of the effect of vaccination used worldwide on the morphology of the spleen of chickens. The received data of a complex assessment of the morphofunctional state of the bird's spleen at different ages should be taken into account when compare complex scheme of vaccination.

Key words: immunomorphology, lymphoid nodules of the spleen, periarterial lymphoid vaginas, periellipsoid lymphoid vaginas, vaccinal prevention.

\section{Морфологія селезінки курей та їі зміни за вакцинації}

\author{
С. В. Гуральська, Т. С. Буднік
}

Поліський наџіональний університет, м. Житомир, Украӥна

\footnotetext{
Вивченню процесів імуногенезу у птахів, вакцинованих проти інфекційних захворювань, присвячено значна кількість наукових праць. В більшості випадків, дослідження спрямовані на оцінку поствакцинального імунітету, а також встановлення структурних змін в органах імунного захисту. Адже, саме морфологічні дослідження можуть надати об'єктивну оцінку імунної ефективності вакцини та оцінити стан імунної системи організму. Проте, на сьогодні морфологічний контроль імунного статусу курей у поствакцинальний період не знайшов широкого застосування в практичному птахівництві. Створюючи нові схеми вакцинопрофілактики, фахівиі не беруть до уваги зміни, які проявляються в цей період. Мета статті - систематизувати та описати основні результати проведених досліджень щодо морфології селезінки курей за вакцинаиії. Необхідно відмітити, що серед інфекційних захворювань птиці, особливе місие займають: інфекційна бурсальна хвороба, інфекційний бронхіт, ньюкаслська хвороба, інфекційний ларинготрахеїт тощо. Нині дані захворювання реєструються практично у всіх країнах світу та наносить значні економічні збитки птахогосподарствам. До основних морфологічних змін в селезінці курей за вакцинаиї відносяться гіперпластичні прочеси (проліферація лімфоцитів та збільшення макрофагів), поява бластних клітин, розвиток плазмоцитарної реакиії. Морфофункиіо-
} 
нальні зміни в селезіниі курей за вакиинації відображенні у значній кількості літератури, проте зміни в органі, які виникають за багаторазової вакцинації при проведенні комплексних схем вакцинації недостатньо висвітлені. Ця оглядова стаття містить короткий опис про вплив вакцинації, щцо використовується у всьому світі, на морфологію селезінки курей. Отримані дані комплексної оцінки морфофункціональнального стану селезінки птиці у різні вікові періоди необхідно враховувати при складанні комплесних програм вакцинопрофілактики.

Ключові слова: імуноморфологія, лімфоїдні вузлики селезінки, періартеріальні лімфоїдні піхви, періеліпсоїдні лімфоїдні піхви, вакцинопрофілактика.

\section{ВстуII}

Птахівництво є одним з перспективних напрямків сільського господарства (Sharma, 1999). За останні півстоліття виробництво птиці збільшилось у п’ять разів та продовжує зростати (OECD-FAO, 2016). Адже, сільськогосподарська птиця - це найбільш споживаний у всьому світі тваринний білок (OECDFAO, 2019).

В процесі вирощування птиці основну проблему створюють інфекційні захворювання, як вірусної, так і бактерійної етіології. Вакцинація $є$ основним методом захисту поголів'я птахогосподарств (Sharma, 1999). Проте, негативний вплив техногенних факторів спричиняє розвиток імунодефіцитних станів та знижує ефективність вакцинації. Імунні розлади у більшості випадках виникають через дефект імунної системи або ж нездатність елімінувати антиген. Будьякий фактор, що знижує імунну відповідь, впливає на параметри виробництва. Існує безліч факторів, інфекційних та неінфекційних, що викликають імунодепресію у курей (Gimeno \& Schat, 2018). Основні із причин виникнення імунодефіцитних станів - це порушення умов утримання та годівлі, а також хронічні антропогенні навантаження, характерні для сучасного птахівництва. Відповідно реакцією птиці $€$ пригнічення активності клітинних і гуморальних механізмів природного захисту, зниження імунної резистентності, дефіциту Т-лімфоцитів, гальмування синтезу антитіл, порушення переробки антигенної інформації. Все це створює умови щодо зростання сприйнятливості до умовно-патогенних мікроорганізмів (Bushuyeva et al., 2014).

Селезінка курей являється одним із основних органів імунного захисту (Zhang et al., 2019). Її стійкість до захворювань, на думку Kozlu et al. (2011); Zhang et al. (2015) посилюється завдяки відсутності лімфатичних вузлів у курей. Селезінка дуже чутлива до змін, як зовнішнього, так і внутрішнього середовища (Dunaievska, 2018). За дії різних несприятливих факторів (Graczyk et al., 2003), зокрема і вакцинації (Guralska, 2016; Stromberg et al., 2018), різних захворювань (Al-Khatib \& Al-Qutbey, 2005; Yang et al., 2006; Sandford et al., 2011) змінюється склад імуннокомпотентних клітин та будова самого органу. Li et al., (2020) стверджують, що стрес, спричинений вакцинацією викликає апоптоз у лімфоцитах селезінки. Стресові фактори можуть змінювати імунні реакції (Wilkinson et al., 2011). Тому, важливе значення належить дослідженням оцінки морфологічного стану органів імунного захисту.

\section{Результати та їх обговорення}

Формування селезінки, як одного із важливих органів імунного захисту у ранній постнатальний період, $\epsilon$ важливим показником для визначення оцінки стану організму під час формування, а також пристосування до зовнішнього середовища (Kotarev, 2020). Будова селезінки у процесі еволюційного розвитку ускладнюється та вдосконалюється (Goralskiy et al., 2018). У ранній ембріональний період вона функціонує як гемопоетичний орган, з'являються еритропоез та мієлопоез, пізніше лімфопоез (Yassine et al., 1989). У цей період структура селезінки є “незрілою”, ретикулярні волокна з'являються пізніше (Fukuta \& Mochizuki, 1982). Незріла гемопоетична структура органу більш нагадує червону пульпу, вона складається 3 капілярів та пульпових канатиків, де синуси відповідають за еритропоез, а позасудинні ділянки за мієлопоез. Селезінка птахів, на відміну від ссавців, не виконує такої функції, як депо крові (Finogenova, 2009).

Селезінка відноситься до основної ланки в імунітеті птиці (Mustafa \& El-Desoky, 2020). Найбільш характерною ознакою строми органу є тонка капсула, а також відсутність трабекул (Colombatti, 1989; Mustafa \& El-Desoky, 2020). За даними Kannan et al. (2015), Guralska (2011) селезінка курей містить сполучнотканинну капсулу, а трабекули слабко розвинені. В той же час Akter (2016) відмічає, що селезінка птиці вкрита товстою капсулою, та підтверджує дані Kannan et al. (2015), Guralska (2011) щодо наявності невеликої кількості трабекул.

У будь-якому віці паренхіма селезінка складається із червоної та білої пульпи. Біла пульпа має в своєму складі періеліпсоїдні лімфоїдні піхви, періартеріальні лімфоїдні піхви та лімфоїдні вузлики. Вона містить ретикулярні клітини та ретикулярні волокна, у яких дифузно розміщені імунокомпетентні клітини (Akter, 2016). За даними Kannan et al. (2015), основними клітинами білої пульпи є лімфобласти, лімфоцити, фолікулярні дендритні клітини та ретикулоцити.

В перші тижні життя курей найбільш розвиненими $\epsilon$ періартеріальні лімфоїдні піхви. За гістологічного дослідження Reshag \& Hamza (2017) в селезінці курей 21-добового віку відмічали періеліпсоїдні лімфоїдні піхви, лімфоїдні вузлики, та окрім лімфоцитів, у білій пульпі наявні плазмоцити. У лімфоїдному вузлі селезінки курей 30-добового віку автори спостерігали наявність зародкового центру. Тобто, селезінка вже добре розвинена у 20-30-добовому віці. Проте, Ауman (2021), у своїх дослідженнях відмічав появу білої пульпи, а саме лімфоїдних вузликів у курей 14добового віку. Budnik \& Guralska (2021) в білій пульпі 
селезінки курей спостерігали і лімфоїдні вузлики, і періартеріальні лімфоїдні піхви (тяжі біля пульпарних артерій), а також навколо еліпсоїдних артеріол - періеліпсоїдні лімфоїдні піхви. Ці дані результатів досліджень свідчать про морфофункціональну зрілість лімфоїдної тканини в селезінці, а також про її участь в захисних реакціях організму.

За даними Onyeanusi (2006), в 2-тижневому віці птиці червона і біла пульпа займали практично однакову площу паренхіми органу, а в 3-тижневому віці червона пульпа охоплювала більшу площу. Зародкові центри лімфоїдних вузликів вперше виявлені на 13тижневому віці птиці.

Mast \& Goddeeris (1999) стверджують, що типові структури селезінки, такі як періартеріальна лімфоїдна піхва та еліпсоїди з оточуючим їх кільцем макрофагів, формуються лише в 20-добовому віці курей. Ці структури та зокрема В-зона (періеліпсоїдна лімфоїдна піхва) поступово дозрівають протягом першого тижня життя курей. Як показали в своїх дослідженнях Goralskiy \& Guralska (2013) в селезінці курей лімфоїдні утворення вперше виявлені у 20-добовому віці, які дифузно окутують судини. В цей час спостерігається також формування лімфоїдних вузликів.

У селезінці птиці Т- і В-залежні зони диференційовані. Так, В-зони - це гермінативні центри лімфоїдних вузликів та періеліпсоїдні піхви, а Т-зони - періартеріальні лімфоїдні піхви (Jeurissen, 1991; Kasai et al., 1995; Wu et al., 2012). Відомо, що біла пульпа селезінки курей відіграє життєво важливу роль за початкової імунної відповіді (Gumati et al., 2003; Mebius \& Kraal, 2005; Zhang et al., 2017).

Червона пульпа переважно утворюється еритроцитами, гранулоцитами, макрофаги, поодинокими Тлімфоцитами та плазматичними клітинами (Jeurissen, 1991; Kannan et al., 2015; Akter, 2016).

Артеріоли в червоній пульпі, утворюють еліпсоїди (Kannan et al., 2015). Еліпсоїди більш численніші (Mustafa \& El-Desoky, 2020), це унікальна структура, яка функціонує, як бар'єр для фільтрації та фагоцитозу (Zhang, 2015) та відіграють важливу роль у імунній відповіді (Kasai et al., 1995). Еліпсоїди - це екстраваскулярні ділянки селезінки, їх сітку формують фібробластичні ретикулоцити (Kasai et al., 1995). За даними Zhang et al. (2015) ретикулярні волокна щільно розміщені в еліпсоїді. Ретикулоцити та макрофаги допомагають еліпсоїдам контролювати рух самих клітин та антигенів між кровоносними судинами та білою пульпою (Colombatti et al., 1989). В еліпсоїді та періеліпсоїдних лімфоїдних піхвах знаходиться кров'яноселезінковий бар'єр, який захищає селезінку від проникнення циркулюючих патогенів. Це сітчастий каркас між венозними та артеріальними судинами. До складу кров'яно-селезінкового бар'єру входять ендотеліальні клітини кубоподібної форми, макрофаги, опорні клітини, ретикулярні клітини та волокна (Zhang et al., 2015). У своїх дослідженнях Zhang (2019) відмічали, що із збільшенням віку курей кров'яно-селезінковий бар'єр селезінки розвивався і структурно, і функціонально. Еліпсоїди мають функціональний взаємозв'язок не лише з регуляцією кро- вотоку, а також з транспортом антигену та лімфоцитів (Sapin, 1998). Клітини, асоційовані з еліпсоїдами, після захоплення антигену мігрують 3 еліпсоїда i з'являються в періартеріальних піхвах та утворюють світлі центри (Igyarto et al., 2007).

Селезінка відіграє вирішальну роль у клітинному та гуморальному імунітеті. Одним із важливих досліджень щодо наявності лімфоцитів, які в основному відповідають за імунітет, є гістоархітектоніка селезінки (Yabe et al., 2017).

Розвиток птахівництва в Україні, наявність також великої кількості невеликих фермерських господарств, потребує постійного контролю щодо розповсюдження інфекційних хвороб птиці (Rula, 2012).

В умовах промислового птахівництва виникає небезпека виникнення інфекційних хвороб, які призводять до значних економічних втрат. Для забезпечення стійкого епізоотичного благополуччя 3 інфекційних хвороб птахів поряд із загальними ветеринарносанітарними заходами широко застосовуються різні схеми імунізації з використанням живих та інактивованих вакцин (Gromov et al., 2013).

В організації програм специфічної профілактики інфекційних хвороб у птахогосподарствах значні перешкоди створюють змішані інфекції, тому реалізується досить велика кількість вакцинацій, причому терміни їх проведення часто співпадають (Yang et al., 2011). Удосконалення специфічної профілактики інфекційних захворювань шляхом розробки методів асоційованої вакцинації проти декількох захворювань $\epsilon$ актуальним завданням. Нині перевагу віддають комбінованим вакцинам, тому що застосовується одна доза препарату проти декількох інфекцій (Wilkinson et al., 2011). Імунізація - найважливіший захід щодо контролю інфекційних захворювань, проте масове використання живих вакцин призвело до еволюції нових штамів (Dey et al., 2019). Так, методи повторної імунізації інактивованими вакцинами широко використовуються для підвищення захисту антитіл від вірусу інфекційного бронхіту. Однак, у порівнянні з ДНКвакцинами, ці методи зазвичай спричиняють погану клітинну реакцію (Guo et al., 2010). За даними Cavanagh (2003) інактивовані вакцини є недостатньо ефективними, якщо застосовувати їх одноразово. Живі аттенуйовані вакцини забезпечують добрий, хоча і короткочасний захист (Cavanagh, 2003).

Вже в молодому віці курчата повинні впоратися 3 хронічними стресовими факторами, які можуть погіршити їхне здоров'я та добробут, причому щільність поголів'я є одним 3 найвпливовіших факторів (Hofmann, 2021). За даними результатів дослідження Asrutdinova et al. (2020) застосування вакцини має слабкий реактогенний ефект. При цьому, у селезінці курей слабко виражена гіперплазія клітин лімфоїдної тканини, а щільність тимусозалежних лімфоцитів у періартеріальній лімфоїдній піхві низька.

У своїх дослідженнях Al-Zubeady et al. (2018) виявляли патологічні зміни у селезінці вакцинованих курей. Причому Eto et al. (2018), за вакцинації курейнесучок у селезінці гістологічних змін не спостерігали. При цьому, Goralskiy \& Guralska (2013) у своїх 
дослідженнях вказують, що вакцинація курей стимулює розвиток імунних утворень, так як формування лімфоїдних вузликів селезінки спостерігається у 20добовому віці птиці.

Проблемам специфічної профілактики при вирощуванні курей присвячено багато наукових робіт, наразі серед них домінують дослідження 3 програм профілактики таких захворювань, як інфекційна бурсальна хвороба, ньюкаслська хвороба, інфекційний ларинготрахеїт, інфекційний бронхіт.

За даними Gromov et al. (2006) морфологічні зміни в селезінці птахів за вакцинації проти інфекційної бурсальної хвороби супроводжується збільшенням органометричних показників кількості лімфоїдних вузликів, а також посиленням бласттрансформації лімфоцитів і плазматизації. Під впливом вакцинного антигену в селезінці молодняка курей спостерігається підвищення активності фосфатаз. Дослідження Yasmin et al. (2016), показали, що вірус інфекційної бурсальної хвороби уражає лімфоїдні клітини, переважно В-лімфоцити та макрофаги. Scanavini Neto et al. (2004) провели мікроскопічний аналіз селезінки за вакцинації проти інфекційної бурсальної хвороби та спостерігали імунну відповідь, що характеризується гіперплазією ретикулоендотеліальних клітин у періартеріальній лімфоїдній піхві та збільшенням кількості зародкових центрів лімфоїдних вузликів органу.

За імунізації проти ньюкаслської хвороби спостерігається в селезінці курей розвиток вираженої і тривалої плазматизації, а також достовірне зростання органометричних показників, зокрема зростання плазмоцитів (Gromov \& Prudnikov, 2009). Ці результати узгоджуються $з$ даними Golubev et al. (2003), які в своїх дослідженнях спостерігали активізацію бластної і плазмоцитарної реакції в селезінці курей за вакцинації проти ньюкаслської хвороби. За результатами дослідження Masum et al. (2014), у селезінці вакцинованих курей плазмоцити розміщені в білій пульпі, зокрема навколо центральної артерії, в періартеріальній лімфоїдній піхві та навколо трабекул. Мобілізація більшої кількості плазмоцитів у лімфоїдних тканинах курей зумовлена впливом вакцини проти ньюкаслської хвороби, а також зростанням віку птиці (Masum et al., 2014).

Морфологічні зміни селезінки птахів за вакцинації проти інфекційного ларинготрахеїта супроводжується достовірним збільшенням кількості плазмоцитів (Gromov et al., 2005). Схожі зміни у своїх дослідженнях спостерігали в селезінці курей Shutchenko et al. (2012).

За гістологічного дослідження встановлено, що кількість та розміри лімфоїдних вузликів у вакцинованих та невакцинованих курей були майже однаковими, проте при вивченні плазмоцитарної реакції у птахів, за вакцинації проти інфекційного бронхіту, збільшувалась кількість лімфобластов, плазмобластів, а також проплазмоцитів (Gromov \& German, 2008). Подібні зміни в селезінці у птахів за вакцинації проти даного захворювання спостерігали Asrutdinova et al. (2020). У своїх дослідженнях Asrutdinova et al. (2020) відмічали зростання проліферації та диференціації лімфоцитів у численних лімфоїдних вузлах селезінки за тривалої дії вакцини проти інфекційного бронхіту. Також спостерігали гіперплазію періартеріальних та періеліпсоїдних лімфоїдних піхв та появу зародкових центрів у лімфоїдних вузликах органу. Згідно з дослідженнями Guralska (2016), після введення вакцини проти інфекційного бронхіту відбувається зростання Т-клітин селезінки. Також у вакцинованих курчат відмічали зменшення індексу органів імунного захисту, зокрема селезінки (Guralska, 2015). Подібні зміни також в своїх дослідженнях спостерігали Scanavini Neto et al. (2004).

Rautenschlein et al. (2005), Thomrongsuwannakij et al. (2021) висловлюють думку, що перш ніж застосовувати певні вакцини проти інфекційних захворювань необхідно вивчити імунний статус курчат, небезпеку виникнення спалахів хвороби.

\section{Висновки}

Вивчення морфологічних особливостей селезінки птахів за вакцинації $є$ одним із важливих кроків для розвитку імуноморфології та вакцинопрофілактики. Велика кількість праць присвячена вивченню морфології селезінки курей, проте на сьогодні залишаються питання невизначеності закономірностей формування імунної відповіді у птиці за умови різного антигенного навантаження. Тому дані дослідження мають великий науковий інтерес. У перспективі подальших досліджень планується провести дослідження щодо впливу багатократних вакцинацій на органи імунного захисту курей.

\section{References}

Akter, S., Khan, M. Z. I., Jahan M. R., Karim M. R. \& Islam M. R. (2006). Histomorphological study of the lymphoid tissues of broiler chickens. Bangladesh Journal of Veterinary Medicine, 4(2), 87-92. doi: 10.3329/bjvm.v4i2.1289.

Al-Khatib, G. M., \& Al-Qutbey, S. H. (2005). Isolation and Identification of Salmonella spp. which contaminated Poultry slaughter houses. The Iraqi Journal of Veterinary Medicine, 29(1), 92-97. doi: 10.30539/iraqijvm.v29i1.868.

Al-Zubeady, A. Z., Shamaun, A. A., \& Mahmmod, A. (2018). Histopathological And Immune Response Against Infectious Bursal Disease In Chickens Vaccinated Against Newcastle Disease. Al-Qadisiyah Journal of Veterinary Medicine Sciences, 12(1), 6670. doi: 10.29079/vol12iss1art232.

Asrutdinova, R., Zalyalov, I., Kirillov, E., Sunagatov, F., \& Dubovoy, A. (2020). Comparative histological changes in the structure of the spleen and kidneys of experimental chickens exposed to the action of "Guidamis" as an adjuvant for vaccination against infectious bronchitis. BIO Web of Conferences, 17, 6 . doi: 10.1051/bioconf/20201700184.

Ayman, U., Alam, Md. R., \& Das, S. K. (2021). The spleen of Sonali chicken: morphohistology and biometric analysis at post hatching ages. Asian Journal of 
Medical and Biological Research, 7(1), 69-75. doi: 10.3329/ajmbr.v7i1.53311.

Budnik, T. S., \& Guralska, S. V. (2021). Morphology of the spleen of chickens in the post-vaccination period. Proceedings of the Correspondence Snternational Scientific and Practical Conference "And integrated approach to science modernization methods, modeis and multidisciplinarity". Grail of science, 1, 198-200. doi: 10.36074/grail-of-science.19.02.2021.039.

Bushuyeva, I. V., Berezovsky, A. V., Knysh, E. G., \& Panasenko, O. I. (2014). Zastosuvannya preparatu Avesstymtm dlya pidvyshchennya efektyvnosti vaktsynoprofilaktyky ta vplyv preparatu na rezystentnist' kurchat [The use of the drug Avesstimtm to increase the effectiveness of vaccine prophylaxis and the effect of the drug on the resistance of chickens]. ScienceRise, 4/1(4), 94-97. doi: 10.15587/23138416.2014.29279 (in Ukrainian).

Cavanagh, D. (2003). Severe acute respiratory syndrome vaccine development: experiences of vaccination against avian infectious bronchitis coronavirus. Avian Pathology, 32(6), 567-82. doi: 10.1080/03079450310001621198.

Colombatti, A., Poletti, A., Carbone, A., Volpin, D., \& Bressan, G. M. (1989). Extracellular matrix of lymphoid tissues in the chick. Journal of Histochemistry and Cytochemistry, 37, 757-763. doi: 10.1177/37.5.2703709.

Dey, S., Pathak D. C., Ramamurthy, N., Maity, H. K. \& Chellappa, M. M. (2019). Infectious bursal disease virus in chickens: prevalence, impact, and management strategies. Veterinary Medicine: Research and Reports, 10, 85-97. doi: 10.2147/VMRR.S185159.

Dunaievska, O. (2018). Anatomical and Morphometric Criteria of Spleen in Matured Gallus gallus, forma domestica L., Columbia livia G., Coturnix coturnix L. Innovative Biosystems and Bioengineering, 2(4), 221231. doi: 10.20535/ibb.2018.2.4.151572.

Eto, S. F., Andrade, F. G., Pinheiro, J. W., Balarin, M. R., Ramos, S. P., \& Venancio, E. J. (2012) Effect of inoculation route on the production of antibodies and histological characteristics of the spleen in laying hens. Brazilian Journal of Poultry Science, 14(1), 6366. doi: 10.1590/S1516-635X2012000100011.

Finogenova, Yu. A. (2009). Morfogenez selezenki broylerov [Broiler spleen morphogenesis]. Ekologicheskaya bezopasnost regiona, 372-375 (in Russian).

Fukuta, K., \& Mochizuki, K. (1982). Formation of reticular fibers in the developing spleen of the chick embryo. Archivum histologicum Japonicum, 45, 181189. doi: 10.1679/aohc.45.181.

Gimeno, I. M., \& Schat, K. A. (2018). Virus-Induced Immunosuppression in Chickens. Avian Diseases, 62(3), 272-285. doi: 10.1637/11841-041318-Review.1.

Golubev, D. S., Zhakov, M. S., \& Birman, B. Ya. (2003). Vliyaniye immunostimulyatora kaliya orotata na organizm tsyplyat-broylerov, immunizirovannykh assotsiirovanno protiv n'yukaslskoy bolezni i infektsionnogobronkhita [The effect of the potassium immunostimulant orotate on the organism of broiler chickens immunized against Newcastle disease and infectious bronchitis]. Scientific notes of the educational establishment Vitebsk the Order of "the Badge of Hon- or" State Academy of Veterinary Medicine, 39(1), 44. URL: https://repo.vsavm.by//handle/123456789/9356 (in Russian).

Goralskiy, L. P., \& Guralska, S. V. (2013). Imunomorfohenez u kurey, vaktsynovanykh proty infektsiynoho bronkhitu [Immunomorphogenes of hen's, which was immunized against an infectious bronchitis]. Visnyk ZhNAEU, 2(1), 90-93. URL: $\quad$ http://ir.znau.edu.ua/bitstream/123456789/515/1/ Immunomorfogenesis_in_chickens.pdf(in Ukrainian).

Goralskiy, L. P., Dunaievska, O. F., \& Yaroshenko, T. Ya. (2018). Comparative anatomicallyimmunohistochemical characteristics of spleen in representatives of birds and mammals classes. Medical and Clinical Chemistry, 20(4), 72-78. doi: 10.11603/mcch.2410-681X.2018.v0.i4.9806.

Graczyk, S., Kuryszko, J., \& Madej, J. (2003). Reactivity of Spleen Germinal Centres in Immunized and ACTHtreated Chickens. Acta Veterinaria Brno, 72, 523531. doi: 10.2754/avb200372040523.

Gromov, I. N., \& German, S. P. (2008). Morfologicheskiye i biokhimicheskiye izmeneniya $\mathrm{v}$ organakh immunnoy sistemy ptits, vaktsinirovannykh protiv infektsionnogo bronkhita [Morphological and biochemical changes in the organs of the immune system of birds vaccinated against infectious bronchitis]. Visnyk ZhNAEU, 1/21(1), 230-237 (in Russian).

Gromov, I. N., \& Prudnikov, V. S. (2009). Morfologiya organov immunnoy sistemy molodnyaka kur pri assotsiirovannoy vaktsinatsii protiv infektsionnoy bursal'noy bolezni, infektsionnogo bronkhita i bolezni N'yukasla [Morphology of the organs of the immune system of young chickens during associated vaccination against infectious bursal disease, infectious bronchitis and Newcastle disease]. Scientific notes of the educational establishment Vitebsk the Order of "the Badge of Honor" State Academy of Veterinary Medicine, 45(1/2), 149-153 (in Russian).

Gromov, I. N., Galenko, S. S., Nasonov, I. V., Kostyuk, N. I. \& Bubashko O. A. (2013). Izucheniye sravnitel'noy immunologicheskoy effektivnosti assotsirovannykh vaktsin protiv n'yukaslskoy bolezni, infektsionnogo bronkhi ta i sindroma snizheniya yaytsenoskosti v proizvodstvennykh usloviyakh [Study of the comparative immunological efficacy of associative vaccines against Newcastle disease, infectious bronchitis, and egg production syndrome under industrial conditions]. Scientific notes of the educational establishment Vitebsk the Order of "the Badge of Honor" State Academy of Veterinary Medicine, 49(1/1), 18-21 (in Russian).

Gromov, I. N., Prudnikov, V. S., \& Birman, B. Ya. (2005). Morfologicheskaya otsenka effektivnosti vaktsinatsii kur protiv ILT [Morphological evaluation of the effectiveness of vaccination of chickens against ILT]. Scientific notes of the educational establishment Vitebsk the Order of "the Badge of Honor" State Academy of Veterinary Medicine, 41(1), 95-97 (in Russian).

Gromov, I. N., Prudnikov, V. S., Gospodarik, O. V., \& Zakharenko, M. V. (2006). Morfometricheskiye pokazateli organov immuniteta ptits, vaktsinirovannykh 
protiv infektsionnoy bursal'noy bolezni [Morphometric indicators of the organs of immunity of birds vaccinated against infectious bursal disease]. Scientific notes of the educational establishment Vitebsk the Order of "the Badge of Honor" State Academy of Veterinary Medicine, 42(1/1), 50-53 (in Russian).

Gumati, M. K., Magyar, A., Nagy, N., Kurucz, E., Felfoldi, B., \& Olah, I. (2003). Extracellular matrix of different composition supports the various splenic compartments of guinea fowl (Numida meleagris). Cell and Tissue Research, 312, 333-343. doi: 10.1007/s00441-003-0736-y.

Guo, Z., Wang, H., Yang, T., Wang, X., Lu, D., Li, Y., \& Zhang, Y. (2010). Priming with a DNA vaccine and boosting with an inactivated vaccine enhance the immune response against infectious bronchitis virus. Journal of Virological Methods, 167(1), 84-89. doi: 10.1016/j.jviromet.2010.03.016.

Guralska, S. V. (2011). Morfolohiya selezinky kurey krosu khayseks, vaktsynovanykh proty infektsiynoho bronkhitu [Morphology of hen's spleen of cross-breed of khayseks, which was immunized against an infectious bronchitis]. Scientific journal of National University of Live and Environmental Sciences of Ukraine, 167(2), 82-85 (in Ukrainian).

Guralska, S. V. (2015). Morfolohichni zminy orhaniv krovotvorennya ta imunohenezu kurey, vaktsynovanykh proty infektsiynoho bronkhitu [Morphological changes in blood forming and immune organs of chickens, vaccinated against infectious bronchitis]. Scientific journal of National University of Live and Environmental Sciences of Ukraine, 217(1), 47-52 (in Ukrainian).

Guralska, S. V. (2016). Immunohistochemical characterization of lymphocyte subpopulations in the spleen of chickens after vaccination against infectious bronchitis. Scientific Messenger of LNU of Veterinary Medicine and Biotechnologies. Ser.: Veterinary Sciences, 18(3), 62-66. doi: 10.15421/nvlvet7014 (in Ukrainian).

Hofmann, T., Schmucker, S., Grashorn, M., \& Stefanski, V. (2021). Short- and long-term consequences of stocking density during rearing on the immune system and welfare of laying hens. Poult Science, 100(8), 101243. doi: 10.1016/j.psj.2021.101243.

Igyarto, B.-Z., Magyar, A., \& Olah, I. (2007). Origin of follicular dendritic cell in the chicken spleen. Cell Tissue Research, 327, 83-92. doi: 10.1007/s00441-0060250-0.

Jeurissen, S. H. M. (1991). Structure and function of the chicken spleen. Research in Immunology, 142(4), 352-355. doi: 10.1016/0923-2494(91)90090-6.

Kannan, T. A., Ramesh, G., Ushakumari, S., Dhinakarraj, G., \& Vairamuthu, S. (2015). Electron Microscopic Studies of Spleen in Chicken (Gallus domesticus). International Journal of Advanced Veterinary Science and Technology, 4(1), 160-165. doi: 10.23953/ cloud.ijavst. 180 .

Kasai, K., Nakayma, A., Ohbayashi, M., Nakagawa, A., Saga, A., Ito, M., Saga, S., \& Asai, J. (1995). Immunohistochemical characteristic of chicken spleen ellipsoids using newly established monoclonal antibod- ies. Cell and Tissue Research, 281, 135-141. doi: 10.1007/BF00307967.

Kotarev, V. I., Mikhailov, E. V., Khokhlova, N. A., Chaplygina, Yu. A., Samuilenko, A. Yu., Falkova, Yu. O. \& Misharin, I. I. (2020). Histomorphometric indicators of chicken-broilers spleen of the cobb-500 cross within the species-specific interferon. BIO Web of Conferences, 17, 00100 doi: 10.1051/bioconf/20201700100.

Kozlu, T., Sart, E. K., Bozkurt, Y A., \& Altunay, H. (2011). Comparative study on histological structure of the spleen sn the ostrich (Struthio Camelus), the kestrel (Falco Tinnunculus) and the osprey (Pandion Haliaetus). Acta Biologica Hungarica, 62(2), 113 121. doi: 10.1556/ABiol.62.2011.2.1.

Li, R. F., Liu, S. P., Yi, J. E., Tian, Y. N., Wu, J., \& Wen, L. X. (2020). Effects of induced stress from the live LaSota Newcastle disease vaccination on the growth performance and immune function in broiler chickens. Poultry Science, 99(4), 1896-1905. doi: 10.1016/j.psj.2019.12.004.

Mast, J., \& Goddeeris, B. M. (1999). Development of immunocompetence of broiler chickens. Veterinary Immunology and Immunopathology, 70(3/4), 245256. doi: 10.1016/s0165-2427(99)00079-3.

Masum, Md. A., Khan, M. Z. I., Nasrin, M., Siddiqi, M. N. H., Khan, M. Z. I. \& Islam, M. N. (2014). Detection of immunoglobulins containing plasma cells in the thymus, bursa of Fabricius and spleen of vaccinated broiler chickens with Newcastle disease virus vaccine. International Journal of Veterinary Science and Medicine, 2(2), 103-108. doi: 10.1016/j.ijvsm.2014.06.001.

Mebius, R. E., \& Kraal, G. (2005). Structure and function of the spleen. Nature Reviews Immunology, 5(8), 606-616. doi: 10.1038/nri1669.

Mustafa, F. E. Z. A., \& El-Desoky, S. M. M. (2020). Architecture and Cellular Composition of the Spleen in the Japanese Quail (Coturnix japonica). Microscopy and Microanalysis, 26(3), 589-598. doi: $10.1017 / \mathrm{S} 143192762000152 \mathrm{X}$.

OECD/FAO (2016). OECD-FAO Agricultural Outlook 2016-2025. Paris: OECD Publishing, 107-116. doi: 10.1787/agr_outlook-2016-en.

OECD/FAO (2019), OECD-FAO Agricultural Outlook 2019-2028, OECD Publishing, Paris/Food and Agriculture Organization of the United Nations, Rome, 166-167. doi: 10.1787/agr_outlook-2019-en.

Onyeanusi, B. I. (2006). The guinea fowl spleen at embryonic and post-hatch periods. Anatomy, Histology and Embryology, 35(3), 140-143. doi: 10.1111/j.1439-0264.2005.00641.x.

Rautenschlein, S., Kraemer, Ch., Vanmarcke, J., \& Montiel, E. (2005). Protective efficacy of intermediate and intermediate plus infectious bursal disease virus (IBDV) vaccines against very virulent IBDV in commercial broilers. Avian Diseases, 49(2), 231-237. doi: 10.1637/7310-112204R.

Reshag, A. F., \& Hamza, R. A. (2017). Anatomical and histological changes in the spleen of post hatching indigenous chicken in Iraq. The Iraqi Journal of Veterinary Medicine, 41(2), 174-178. URL: https://www.iasj.net/iasj/article/139814. 
Rula, O. M. (2012). Shlyakhy zabezpechennya epizootychnoho blahopoluchchya ptakho hospodarstv Ukrayiny shchodo infektsiynoyi bursal'noyi khvoroby (khvoroby Hamboro) [Ways to ensure the epizootic welfare of poultry farms in Ukraine for infectious bursal disease (Gamboro disease)]. Veterinary medicine, 96, 230-232 (in Ukrainian).

Sandford, E. E., Orr, M., Balfanz, E., Bowerman, N., Li, X., Zhou, H., Johnson, T. J., Kariyawasam, S., Liu, P., Nolan, L. K., \& Lamont, S. J. (2011). Spleen transcriptome response to infection with avian pathogenic Escherichia coli in broiler chickens. BMC Genomics, 12, 469-482. doi: 10.1186/1471-2164-12-469.

Sapin, M. R., \& Bulanova, G. V. (1988). Ellipsoids of the spleen (ellipsoid macrophagal-lymphoid sheaths. Arkhiv anatomii, gistologii i embriologii, 95(12), 513. URL: https://pubmed.ncbi.nlm.nih.gov/3073724.

Scanavini Neto, H., Ito, N. M. K., Miyaji, C. I., Lima, E. de A., Okabayashi, S., Correa A. R. A., Eleuterio, G. C., \& Zuanaze, M. A. (2004). Infectious bursal disease virus: case report and experimental studies in vaccinated and unvaccinated SPF chickens and commercial broiler chicks. Brazilian Journal of Poultry Science, 6(1), 41-54. doi: 10.1590/S1516-635X2004000100006.

Sharma, J. M. (1999). Introduction to poultry vaccines and immunity. Advances in Veterinary Medicine, 41, 481-94. doi: 10.1016/s0065-3519(99)80036-6.

Shutchenko, P. O., Stegniy, B. T., Music, D. V., Medvid, K. O., Stegniy, A. B., Rula, O. M. \& Tkachenko, S. V. (2012). Doslidzhennya histolohichnykh zmin v orhanakh imunnoho zakhystu kurchat, eksperymental'no infikovanykh epizootychnym izolyatom virusu infektsiynoho larynhotrakheyitu [Study of histological changes in the immune organs of chickens experimentally infected with an epizootic isolate of infectious laryngotracheitis virus]. Veterinary Medicine, 96, 260-261 (in Ukrainian).

Stromberg, Z. R., Goor, A., Redweik, G. A. J. \& Mellata, M. (2018). Characterization of Spleen Transcriptome and Immunity Against Avian Colibacillosis After Immunization With Recombinant Attenuated Salmonella Vaccine Strains. Frontiers in Veterinary Science, 5, 198. doi: 10.3389/fvets.2018.00198.

Thomrongsuwannakij, T., Charoenvisal, N., \& Chansiripornchai, N. (2021). Comparison of two attenuated infectious bursal disease vaccine strains focused on safety and antibody response in commercial broilers. Veterinary World, 14(1), 70-77. doi: 10.14202/vetworld.2021.70-77.

Wilkinson, K. G., Tee, E., Tomkins, R. B., Hepworth, G. \& Premier, R. (2011). Effect of heating and aging of poul- try litter on the persistence of enteric bacteria. Poultry Science, 90, 10-18. doi: 10.3382/ps.2010-01023.

Wu, B., Cui, H., Peng, X., Fang, J., Cui, W., \& Liu, X. (2012). Pathology of spleen in chickens fed on a diet deficient in methionine. Scientific Research, 4(1), 8. doi: 10.4236/health.2012.41007.

Yabe, M., Medeiros, L., Wang, S., Tang, G., BuesoRamos, C., Jorgensen, J., Bhagat, G., Chen, W., Li, S., Young, K., \& Miranda, R. (2017). Distinguishing Between Hepatosplenic T-cell Lymphoma and $\gamma \delta$ T-cell Large Granular Lymphocytic Leukemia: A Clinicopathologic, Immunophenotypic, and Molecular Analysis. The American Journal of Surgical Pathology, 41(1), 82-93. doi: 10.1097/PAS.0000000000000743.

Yang, X. J., Li, W. L., Feng, Y., \& Yao, J. H. (2011). Effects of immune stress on growth performance, immunity, and cecal microflora in chickens. Poultry Science, 90, 2740-2746. doi: 10.3382/ps.2011-01591.

Yang, X., Guo, Y. M., Wang, Z., \& Nie, W. (2006). Effects of dietary supplementation with different oils on coccidiosis in chickens. Avian Pathology, 35(5), 373 378. doi: 10.1080/03079450600921149.

Yasmin, A. R., Yeap, S. K., Hair-Bejo, M., \& Omar, A. R. (2016). Characterization of Chicken SplenicDerived Dendritic Cells Following Vaccine and Very Virulent Strains of Infectious Bursal Disease Virus Infection. Avian Diseases, 60(4), 739-751. doi: 10.1637/11275-091315-Reg.1.

Yassine, F., Fedecka-Bruner, B., \& Dieterlen-Lievre, F. (1989). Ontogeny of the chick embryo spleen - a cytological study. Cell Differentiation and Development, 27, 29-45. doi: 10.1016/0922-3371(89)90042-7.

Zhang, Q., Chen, B., Yang, P.L., Zhang, Y., Liu, S., Wu, Y., Waqas, Y., Le, W., \& Chen, Q. (2015). Identification and structural composition of the bloodspleen barrier in chicken. The Veterinary Journal, 204, 110-116. doi: 10.1016/j.tvj1.2015.01.013.

Zhang, Q., Sun, X., Wang, T., Chen, B., Huang, Y., Chen, H., \& Chen, Q. (2019). The Postembryonic Development of the Immunological Barrier in the Chicken Spleens. Journal of Immunology Research, 4, 1-10. doi: 10.1155/2019/6279360.

Zhang, Q., Waqas, Y., Yang, P., Sun, X., Liu, Y., Ahmed, N., Chen, B., Li, Q., Hu, L., Huang, Y., Chen, H., Hu, B., \& Chen, Q. (2017). Cytological study on the regulation of lymphocyte homing in the chicken spleen during LPS stimulation. Oncotarget, 8, 74057419. doi: 10.18632/oncotarget.14502. 